\title{
Differences in the improvement rating for the cross test related to practice methods differing in the direction of attention
}

\author{
Hironori Seiki ${ }^{1}$, Motoyoshi Morishita ${ }^{2}$, Issei Hironaka ${ }^{1}$, Ryousuke Ueda ${ }^{1}$ and Mikihiko Harada ${ }^{1}$ \\ ${ }^{1}$ 光市立大和総合病院リハビリテーション部, ₹743-0192 山口県光市大字岩田974番地 (Department of Rehabilitation \\ Medicine Hikari Municipal Yamato General Hospital, 974 Iwata, Hikari-city, Yamaguchi 743-0192, Japan) \\ 吉備国際大学大学院保健科学研究科, 干716-8508 岡山県高梁市伊賀町 8 (Graduate School of Health Sciences Studies, \\ Kibi International University, 8 Iga-machi, Takahasi-city, Okayama 716-8508, Japan)
}

Received: December 26, 2016 / Accepted: May 29, 2017

\begin{abstract}
The purpose of this study was to clarify the effects of external and internal factors (EF and IF, respectively) on attention during exercise on a cross test in elderly inpatients with respect to physical and attention functions. The subjects were 27 elderly inpatients with orthopedic diseases, cerebrovascular diseases, or disuse syndrome (mean age, $77.8 \pm 8.8$ years). They were randomly divided into two groups, and instructed to pay attention in different directions for a cross test. Measurement was conducted in a pretest, during a 14-day period of practice, during a 7-day period of discontinuation, and in a post-test. In the EF group, the subjects were instructed to place their body weight on the floor while paying attention to the floor. In the IF group, they were instructed to tilt their whole body while paying attention to the body. The physical function was evaluated using the Berg Balance Scale and Timed Up and Go Test, attention using the Trail Making Test Part-A. In the EF and IF groups, the physical and attention functions were lower than the reference ranges, and a cross test showed a significant improvement in the EF group both 7 days and post-test. On the other hand, there were no correlations between the improvement rating for the cross test in pre- and post-tests in the EF and IF groups and physical and attention functions. These results suggest that the use of EF improves the cross test in patients with mild physical, attention hypofunction, promoting exercise learning.
\end{abstract}

Jpn J Phys Fitness Sports Med, 66(4): $301-309$ (2017)

Keywords : balance, motor learning

\section{緒言}

運動療法や動作指導を行う際に, 効率的な運動学習を 促すことは動作の再獲得に繋がり，日常生活動作の改善 に重要である。近年, 運動学習において学習者の注意の 向け方の違いにより, 効果が異なることが先行研究で報 告されている ${ }^{1)}$. 注意の向け方として, 運動中の注意を 身体外部へ向けるExternal focus (以下 EF) と身体内部 へ向けるInternal focus（以下 IF）がある。サッカーの キックを例にとると, ボールや蹴る先のゴールに注意を 向けるのが $\mathrm{EF}$ であり, 蹴る足に注意を向けることが IF となる ${ }^{2)}$.

Wulf $~^{3,4)}$ は運動学習の効果の違いについて同じ運動 課題において EFの方がIFよりも運動学習に効果的で あったと報告している. その理由として, 連動学習にIF を用いることは効果的かつ効率的な運動の正常制御過程
に意識的に介入することになり，運動を積極的に制御し ようと試みることは, 自動制御過程を妨害するとされて いる1).

一方, IFを用いることで運動学習が促進的に行われる との見解がある。新しいスキルの学習には, 主に 3 つの 段階として認知段階，連合段階，自動段階があり，運動 学習が進むにつれて運動に必要な注意量は減少するとい われている5)。この考えでは初心者や初めて課題を行う 場合や運動機能が低下したものなどには，身体の動きに 注意を増加させるIFを用いた方が運動学習には効果的 であると考えられる。これらの注意の向け方による $\mathrm{EF}$ とIFの研究を入院患者に応用する場合, 身体機能, 注 意機能が低下している脳血管疾患, 整形外科疾患などの 患者に対する適応について報告が少なく, どのような教 示を用いて運動学習を促せばいいのか明確になっていな い.したがって, 患者の特性に応じた注意の向け方を選 
択できれば患者ひとりひとりに応じたアプローチが可能 となり, 動作を効率的に獲得できる可能性がある。

本研究は回復期リハビリテーション病棟入院患者を対 象とし教示の違いによる運動学習の検証を行った。対 象者を $\mathrm{EF}$ 群, IF 群の 2 群に分け, 教示の違いによる立 位での随意的な安定性限界に及ぼす影響についてCross Testを指標に検証した。

運動学習を「比較的永続的な行動の変化であること ${ }^{6)} 」$ と定義し、今回はプレテストからポストテストまでの Cross Testの改善度を運動学習の効果として, 身体機能, 注意機能から検討を行った。本研究の目的はこれらの機 能に応じた教示の方法を明らかにすることである.

\section{方法}

対象 対象者は回復期リハビリテーション病棟に入院中 の患者 27 名 (脳血管疾患 13 名, 整形外科疾患 9 名, 廃用 症候群 5 名: 平均年齢 $77.8 \pm 8.8$ 歳) の高齢者で, 対象者 の取り込み基準は60秒以上立位保持が可能なもの, Mini Mental State Examination (以下 MMSE) が24点以上 で認知症の疑いがないもの, 脳血管疾患患者は下肢の Brunnstrom Recovery Stage（以下 BRS）がV以上のも のとした，な㧍，運動中に疼痛を生じたり，整形外科疾 患などで足関節背屈の関節可動域制限を有するものは除 外した。

対象者の $\mathrm{EF}$ 群と IF 群への割付は, 取り込み基準を満 たしたものから順に 1 ブロックを 4 名としたブロックラ ンダム化の手法を用い 2 群に割付けた。 2 群への割付 けは 6 パターン $(1: \mathrm{EF} \cdot \mathrm{EF} \cdot \mathrm{IF} \cdot \mathrm{IF}, 2: \mathrm{IF} \cdot \mathrm{IF}$. $\mathrm{EF} \cdot \mathrm{EF}, 3: \mathrm{EF} \cdot \mathrm{IF} \cdot \mathrm{EF} \cdot \mathrm{IF}, 4: \mathrm{IF} \cdot \mathrm{EF} \cdot \mathrm{IF} \cdot \mathrm{EF}$, $5: \mathrm{EF} \cdot \mathrm{IF} \cdot \mathrm{IF} \cdot \mathrm{EF}, 6: \mathrm{IF} \cdot \mathrm{EF} \cdot \mathrm{EF} \cdot \mathrm{IF})$ とし, 乱 数を発生させ始めの整数が $1 \sim 6$ に該当する場合に割付 けた。

対象者の計測期間中の理学療法介入は, 歩行自立に向 けた筋力強化, バランス練習, 動作練習などの通常のプ ログラムを全員に施行した.

本研究はへルシンキ宣言を満たす光市立大和総合病院 の倫理審査委員会の承認（承認番号 H26-1）を得て行っ た. 対象者には書面にて研究の内容について説明し, 署 名にて同意を得て行った。

変数の測定 運動学習の効果の検証としては, Cross Testの改善度を指標とした. Cross Testは月村と池田 ${ }^{7}$ が報告したもので，立位で身体重心を前後左右に動かし た際の重心投影点の軌跡を計測するものである ${ }^{8)}$. 計測 は多目的床反力計（Zebris 社製PDM-S）を使用して計 測者 1 名で行った. Cross Testの計測は立位姿勢で裸足, 足部内側を $10 \mathrm{~cm}$ あけ，上肢は体側におき，視線は前方 を注視させた状態で行った. Cross Testの計測前, 対象
者全員には「できるだけ合図に合わせて体重を前後左右 に移動させるように」と説明をした，EF群は足底と接 している床反力計のプレートに注意を向けさせるため 「床に意識を向けできるだけ体重を床にかけるように」, IF 群は身体内部に注意を向けさせるため「身体に意識を 向けできるだけ身体全体を傾けるように」と教示した。

計測は対象者が床反力計上で立位姿勢となり, 初期の 重心動摇が収まった時点で開始した．5秒間の静止立位 後, 計測者がストップウォッチを見ながら 1 秒ごとにカ ウントした1から 6 の号令をかけ 3 で最大, 6 で中心に 戻るようにして前後左右に重心を動かし, 右方移動後 5 秒間の静止立位で終了とした (Fig. 1). Cross Testの計 測中は踵がプレートから離れたり, 体幹を屈曲, 側屈さ せることなく重心移動が行われるように注意した，計測 者は計測前の 2 回の練習により対象者がCross Testの 方法を理解したことを確認した。解析項目としてX方向 最大振幅とY方向最大振幅の積である矩形面積とした (Fig. 2)。なお，Cross Testに打いては矩形面積の值が 大きいほどバランス能力は良いとされる。 Cross Testは 計測回数における有意な影響は見られず, 疾患の評価や 治療効果の判定に有効とされている ${ }^{8)}$. 身体機能の評価 としてBerg Balance Scale (以下BBS), Timed up and go Test（以下TUG）を使用した. BBSはバランス能力 の指標で座位, 立位での静的な姿勢保持機能, 及び動作 時のバランス機能の評価が可能とされる ${ }^{9)}$. 計測はBerg ら ${ }^{10)}$ の方法に基づいて実施した。TUGは Podsiadloと Richardson ${ }^{11)}$ の方法に基づき椅子座位から $3 \mathrm{~m}$ 前方の 4 脚杖を回り, 着座するまでの時間をストップウォッチ で計測した，計測は 2 回行い速い計測值を採用し，杖や 装具など入院生活で使用しているものは許可した.

また，下肢筋力の測定はManual Muscle Testing（以 下 MMT) を用いプレテストとポストテスト時に股関節, 膝関節，足関節の筋力を Normal, Good, Fair, Poor, Trace, Zeroの6 段階で計測を行った。なお，足関節底 屈がFair 以上の場合, 計測が片足立ちになることから実 施できない対象者が多く, 分析対象から除外した。

注意機能の評価としてTrail Making Test Part-A（以 下TMT-A）を使用した。TMT-A は, 注意障害の検查 でA4 用紙にランダムに配置された 1 ～25までの数字を 順に結んでいき，結び終えるまでの時間を計測するもの である ${ }^{12)}$.

Cross Testの練習 Cross Testの練習は対象者を担当し ている理学療法士に同様の方法で行うように依頼した。 その際，EFと IF の教示は A4 用紙に印刷した文言と同 じように行った. Cross Testの練習頻度は 1 週間で 3 日 とし，1日の施行回数は対象者の状態により $2 \sim 3$ 回と した. 


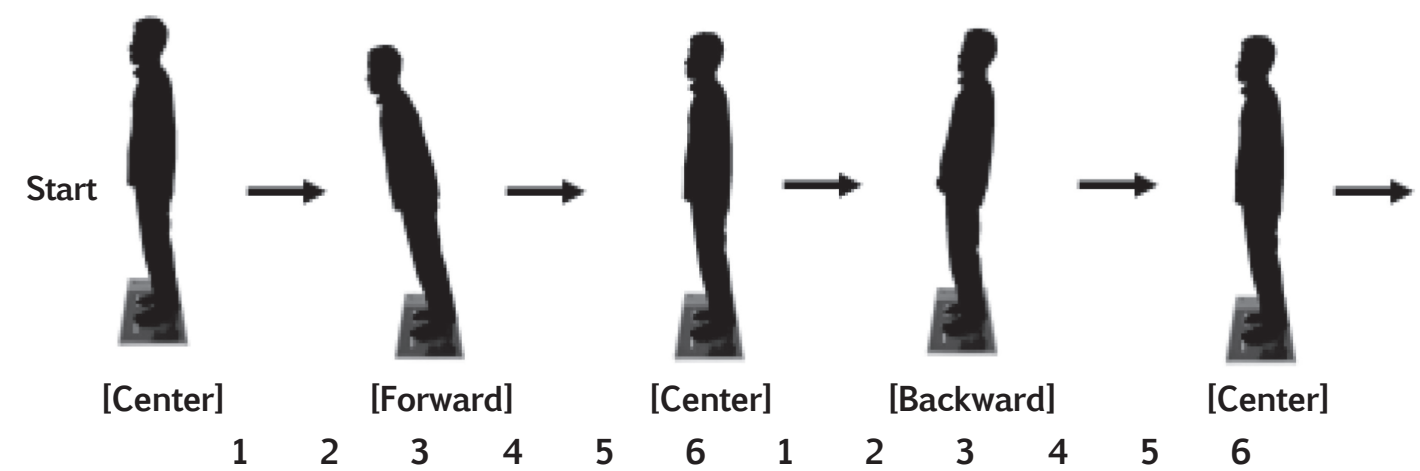

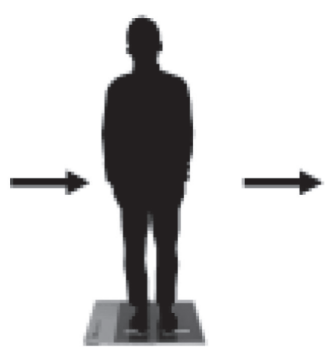

[Center]

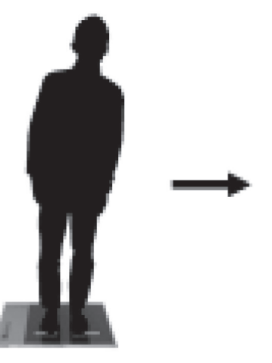

[Left]

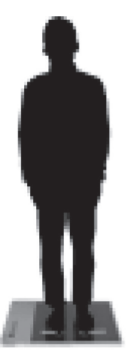

[Center]

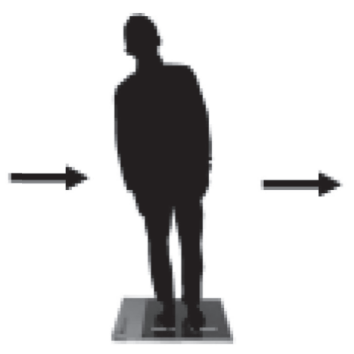

[Right]

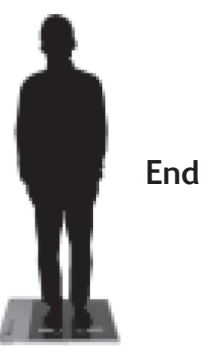

[Center]

\section{2}

4

5

61

2

3

45

6

Fig. 1 Measurement method of Cross Test

During the Cross Test, 1 researcher performed measurement. The subjects were instructed to stand while maintaining a distance of $10 \mathrm{~cm}$ between the inner edges of their feet without shoes, and continuously face forward with their arms at their sides. After standing still for 5 seconds from the initial placement of their center of gravity, they performed the following task while the researcher counted from 1 to 6 using a stopwatch: maximally displacing the center of gravity to the right at the count of 3 ; resuming the initial position at the count of 6 ; and standing still again for 5 seconds. The measurement was performed after explaining the necessity of displacing the center of gravity without heel elevation or trunk flexion/lateral flexion to the subjects, and confirming that they had sufficiently learned the method through 2 rehearsals. ※ Partially modifying and reprinting < Validity of the Cross Test to Evaluate the Equilibrium Function Test $>$ (1994) by Akira Ishikawa et al.

運動学習の検証のこれまでの報告では, 課題の練習回 数や頻度について健常者を対象に課題の練習を連日行う ものや，1日に10回練習を行い調査しているものがみら れた ${ }^{13,14)}$. 本研究におけるCross Testの練習頻度は, 入 院中の高齢者を対象としており, リハビリテーションの 対象疾患の他に心疾患や内科的な疾患を合併しているも のも多く，運動療法も合わせて行っていることなども考 慮し設定した。

計測スケジュール 運動学習の検証を行うため, トラン スファーデザインを採用した（Fig. 3). トランスファー デザインはプレテスト, 練習試行, ポストテストからな るもので練習における一時的な変化を排除し運動学習の 評価を行うことができる6). EF 群と IF 群でCross Test の改善度の検証はベースラインとしてプレテスト, 14 日 間の練習試行，7日間の休止期間後のポストテストの合 計 5 回計測を行った。なお, 計測時に身体機能の評価と してBBS, TUGを同時に計測した。
統計学的分析方法 $\mathrm{EF}$ 群と IF 群の基本属性の比較とし て正規分布しているものには対応のない $\mathrm{t}$ 検定, 仮定 出来ないものにはMann-WhitneyのU検定を行なった. $\mathrm{EF}$ 群と IF 群のBBSと TUGの変化として二元配置分散 分析を行い, Cross Testの矩形面積の経時的な変化と して，プレテストの值を共変量とした共分散分析を行っ た後にBonferroniの多重比較法を行った。EF群と IF 群 のCross Testの矩形面積の改善率〔(ポストテストープ レテスト)/プレテスト×100] とBBS, TUG, TMT-A との関連性の検討はSpearmanの順位相関係数を求め た. TUGとBBSの改善度（ポストテストープレテスト） と EF 群と IF 群のCross Testの矩形面積の改善度（ポ ストテストープレテスト）との関連性の検討については Spearmanの順位相関係数, Pearsonの積率相関係数を用 いた。 また，下肢のMMTにおいてはWilcoxonの符号付 順位和検定を用いてプレテストとポストテストでの同側 の筋力を比較した。

なお, 統計学的有意水準は危険率 $5 \%$ とし二元配置分 


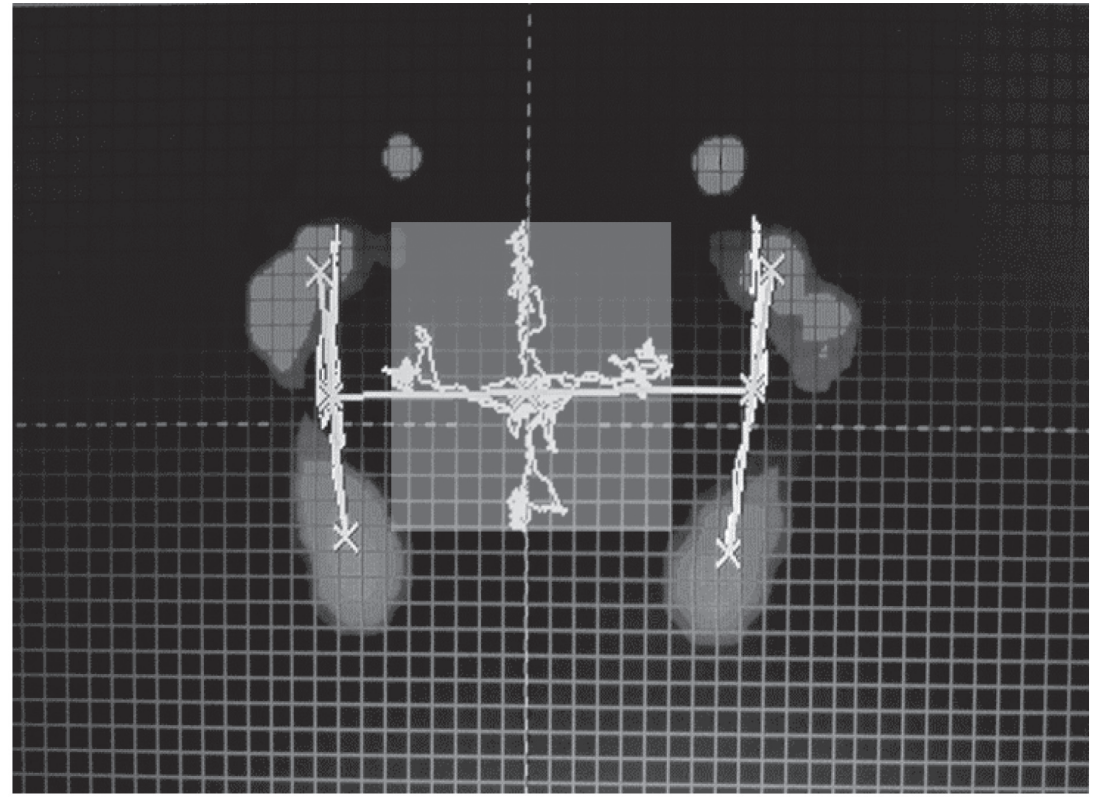

Fig. 2 Rectangular area

The area surrounded by the square in this figure is a rectangular area corresponding to the product of $\mathrm{X}^{-}$and $\mathrm{Y}$-direction maximum amplitudes. On the cross test, the balancing capacity is regarded as more favorable in patients with a larger rectangular area.

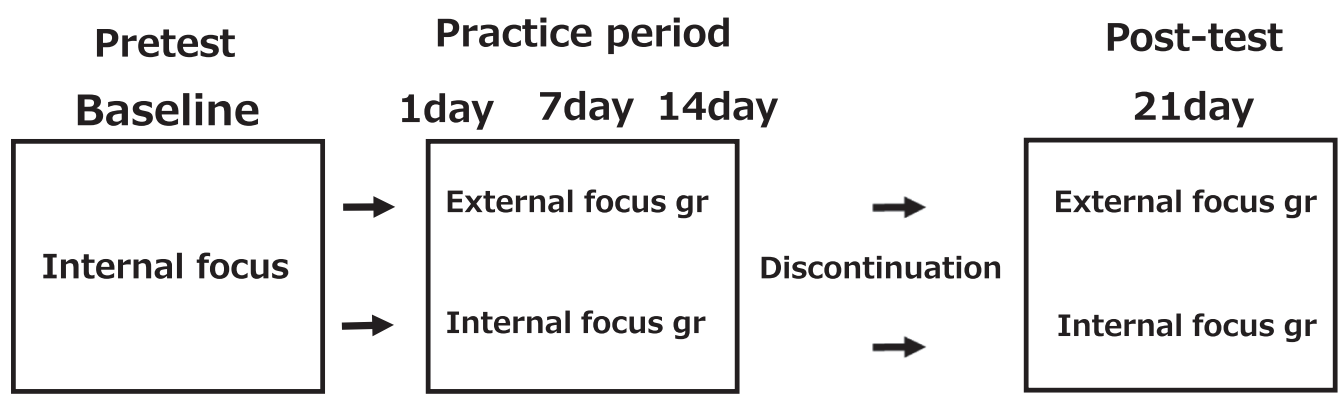

Fig. 3 Measurement schedule

In the EF and IF groups, measurement was conducted 5 times (pretest (baseline), 14-day practice period, and post-test after 7-day discontinuation) to investigate the improvement rating for the cross test.

散分析と共分散分析はIBM SPSS Statistics ver.22，他は フリー統計ソフトEZRを使用した.

\section{結 果}

$\mathrm{EF}$ 群とIF群の基本属性の相違 $\mathrm{EF}$ 群と IF 群の間に基 本属性, 身体機能, 認知機能, 注意機能, 理学療法開始 から計測までの期間について有意差は認められなかった (Table $1 \cdot 2 \cdot 3$ ).

EF群とIF群のCross Test での矩形面積 EF 群と IF 群 のプレテスト，1日目，7日目，14日目，ポストテスト における経時的な矩形面積の変化について，交互作用が 認められ（p<0.05），7日目とポストテストに拀いて EF
群で有意に増加がみられた。 IF 群では有意差はなかっ た (Fig. 4).

計測期間中における BBS・TUGの変化 BBS, TUGの いずれも交互作用が認められず，それぞれの計測時期で 有意な差はなかった（Fig. 5・6）.

EF群とIF群のCross Testにおける矩形面積の改善度と BBS，TUGの改善度の相関係数 いずれも計測期間内 で有意差は認められなかった（Table4）。

EF 群とIF群のCross Testの改善率とBBS, TUG, TMT-A との関係 いずれの項目に押いても相関は認め 
Table 1. Basic characteristics of the subjects

\begin{tabular}{cccc}
\hline & External focus gr & Internal focus gr & P-Value \\
\hline Age & $76.2 \pm 8.6$ & $77.8 \pm 9.4$ & n.s. \\
Height $(\mathrm{cm})$ & $155.4 \pm 9.5$ & $151.5 \pm 9.1$ & n.s. \\
Weight(kg) & $56.3 \pm 9.4$ & $50.1 \pm 10.5$ & n.s. \\
Foot length $(\mathrm{mm})$ & $278.9 \pm 14.3$ & $277.3 \pm 15.7$ & n.s. \\
Foot width $(\mathrm{mm})$ & $228.0 \pm 16.0$ & $222.7 \pm 12.1$ & n.s. \\
TUG $(\mathrm{sec})$ & $18.7 . \pm 13.2$ & $18.6 \pm 8.1$ & n.s. \\
BBS $($ score $)$ & $38.6 \pm 12.4$ & $37.6 \pm 9.8$ & n.s. \\
MMSE (score) & $27.8 \pm 1.5$ & $27.5 \pm 1.6$ & n.s. \\
TMT-A (sec) & $225.6 \pm 102.8$ & $235.5 \pm 106.3$ & n.s. \\
\hline There were no significant differences in any item between the EF and IF \\
groups. \\
mean \pm SD n.s.: not significant
\end{tabular}

Table 2. Basic characteristics of the subjects

\begin{tabular}{|c|c|c|c|c|c|}
\hline & Diacrisis & Age & Sex & Sensation $※ 1$ & BRS $※ 2$ \\
\hline \multirow{12}{*}{ External focus gr } & Lumbar compression fracture & 83 & W & Normal & - \\
\hline & Femoral neck fracture (right) & 89 & W & Normal & - \\
\hline & Contusion of lower leg (right) & 86 & W & Normal & - \\
\hline & Lumbar compression fracture & 74 & W & Normal & - \\
\hline & Lumbar compression fracture & 84 & M & Normal & - \\
\hline & Cervical spondylosis & 80 & W & Hypoesthesia & - \\
\hline & Pontine infarction & 72 & M & Normal & V \\
\hline & Cerebral infarction (right) & 64 & M & Hypoesthesia & V \\
\hline & Cerebral infarction (right) & 64 & $\mathrm{M}$ & Normal & V \\
\hline & Cerebral infarction (right) & 80 & W & Normal & V \\
\hline & Cerebral infarction (right) & 66 & M & Hypoesthesia & $\mathrm{V}$ \\
\hline & Cerebral infarction (right) & 72 & W & Normal & $\mathrm{V}$ \\
\hline \multirow{15}{*}{ Internal focus gr } & Femoral neck fracture (right) & 89 & W & Normal & - \\
\hline & Femoral neck fracture (right) & 90 & W & Normal & - \\
\hline & Polymyositis & 88 & W & Hypoesthesia & - \\
\hline & Cervical burst fracture & 85 & W & Hypoesthesia & - \\
\hline & Lumbar compression fracture & 86 & M & Normal & - \\
\hline & Meningitis & 79 & W & Normal & - \\
\hline & Hypokalemia & 71 & M & Normal & - \\
\hline & Foot burn & 66 & W & Normal & - \\
\hline & Atherothrombotic brain infarction (left) & 70 & W & Normal & VI \\
\hline & Brain hemorrhage (right) & 66 & W & Normal & VI \\
\hline & Acute subdural hematoma & 85 & W & Normal & VI \\
\hline & Acute subdural hematoma & 83 & W & Normal & VI \\
\hline & Cardiogenic cerebral embolism (right) & 65 & M & Normal & V \\
\hline & Cerebellar infarction (right) & 77 & M & Normal & VI \\
\hline & Brain-stem infarction (right) & 67 & W & Normal & V \\
\hline
\end{tabular}

Subject of superficial sensation and grade of paralysis.

$※ 1$ : Sole of foot (Superficial sensation)

$※ 2$ : Brunnstrom Recovery Stage (Lower limbs)

Table 3. Number of days from start of physical therapy to start of measurement

\begin{tabular}{cccc}
\hline & External focus gr & Internal focus gr & P-Value \\
\hline Day & $33.6 \pm 18.9$ & $22.1 \pm 11.3$ & n.s. \\
\hline
\end{tabular}

mean \pm SD n.s.: not significant 


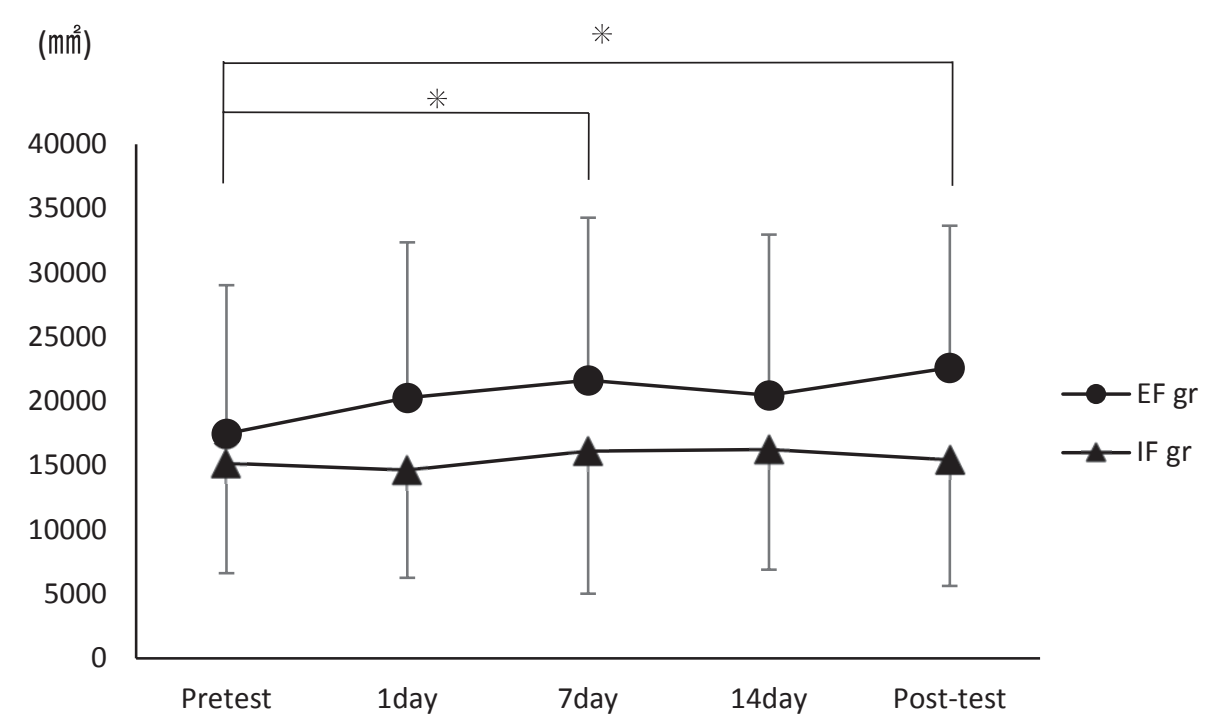

Fig. 4 Rectangular area on the cross test in the EF and IF groups

With respect to the serial changes in the rectangular area in the pretest, on days $1 / 7 / 14$, and in the post-test in the EF and IF groups, there was an interaction between the two groups $(\mathrm{p}<0.05)$.

$\mathrm{EF}$ group in 7 days and post-test were increased significantly, but there was no significant difference in the IF group.

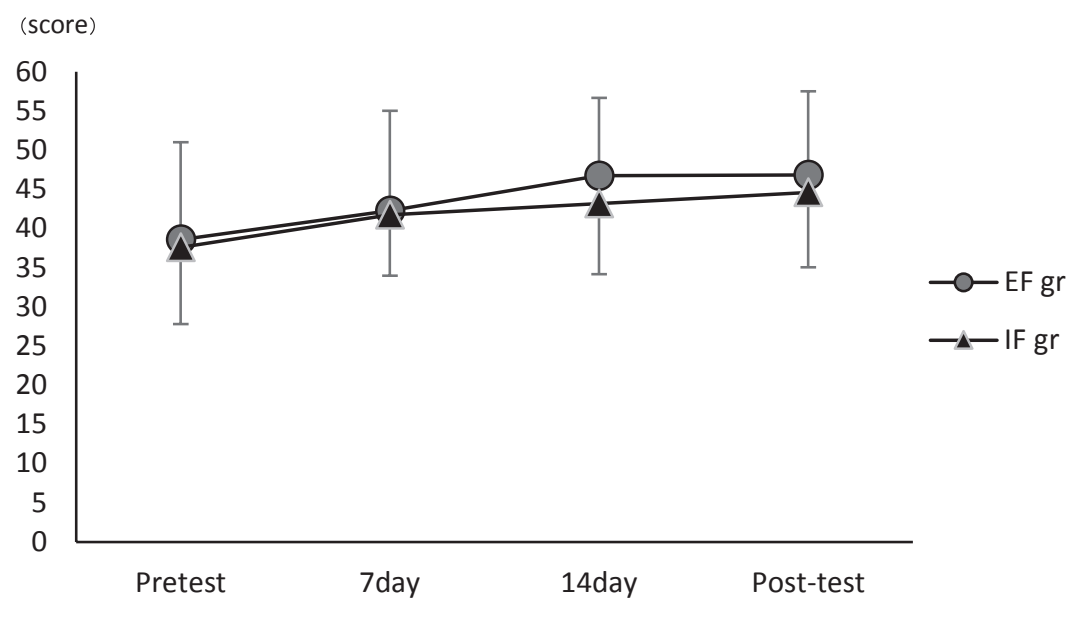

BBS

Fig. 5 Changes in BBS and TUG during the measurement period

Neither TUG nor BBS showed any interaction. There was no significant difference at any point.

られなかった。

$\mathrm{EF}$ 群とIF群のプレテストとポストテスト時での下肢 MMTの比較 いずれも計測期間内で有意差は認められ なかった（Table 5).

\section{考察}

本研究では $\mathrm{EF}$ 群と $\mathrm{IF}$ 群の基本属性やバランス能力, 筋力などの身体機能に扔いて有意差が認められなかった ことから, 運動学習の効果は注意の向け方の違いによる Cross Testの課題特異性であったと考えられる。
Cross Testに扔ける運動学習の効果について, EF 群 で交互作用が認められたことから，入院中の高齢者にお いても $\mathrm{EF}$ の教示を行うことで運動学習が促進的に作用 することが示唆された. Wulf と Mcnevin は ${ }^{15)}$ 健常者を 対象とし床反力計でのバランス練習において, EFを用 い身体外部へ注意を向けることで，立位での重心動摇が 減少したと報告している。また, Chiviacowskyら ${ }^{14)}$ は 平均年齢 69 歳の高齢者 32 人を $\mathrm{EF}$ 群と $\mathrm{IF}$ 群に分け, 不 安定板上で立位バランス練習を行ったところ $\mathrm{EF}$ 群の 方が練習休止後, 効果は持続していたと報告している. Chiviacowsky らの報告と本研究を比較すると, 本研究 


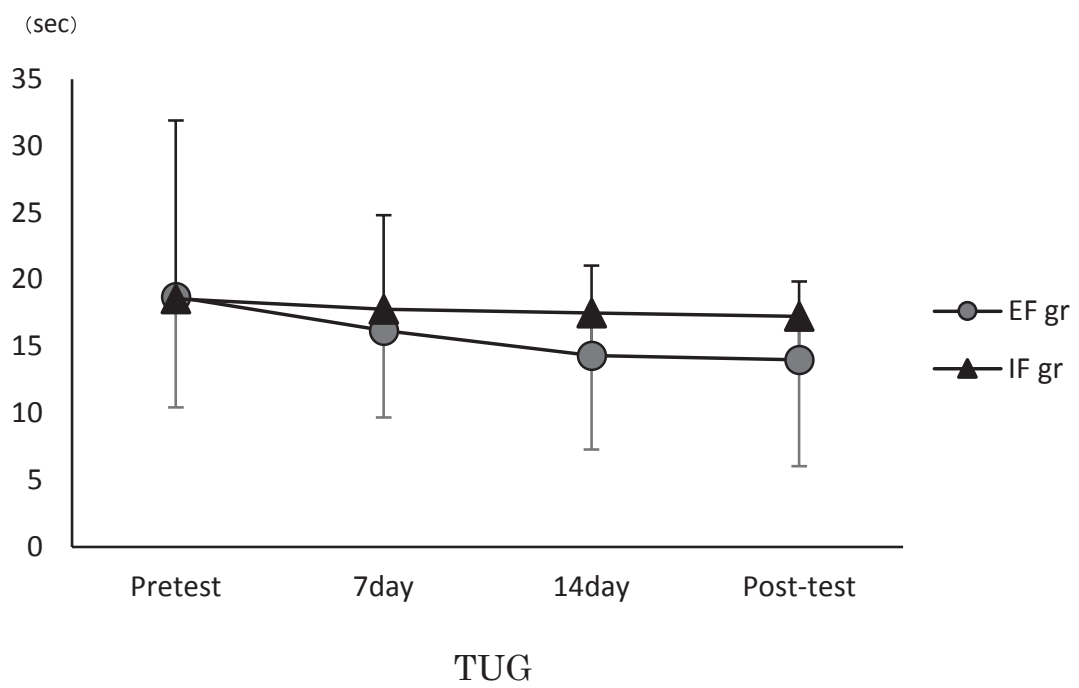

Fig. 6 Changes in BBS and TUG during the measurement period

Neither TUG nor BBS showed any interaction. There was no significant difference at any point.

Table 4. Correlation coefficient of rectangular area improvement and BBS, TUG improvement degree in Cross Test of EF group and IF group

\begin{tabular}{cccc}
\hline & External focus gr & Internal focus gr & P-Value \\
\hline TUG (sec) & 0.37 & 0.15 & n.s. \\
BBS (score) & 0.28 & 0.057 & n.s. \\
\hline
\end{tabular}

n.s.: not significant

Table 5. Comparison of lower limb MMT during pre-test and post-test of EF group and IF group

\begin{tabular}{|c|c|c|c|c|c|c|c|c|c|c|c|}
\hline & & \multicolumn{4}{|c|}{ External focus gr } & \multirow{3}{*}{ P-Value } & \multicolumn{4}{|c|}{ Internal focus gr } & \multirow{3}{*}{$\mathrm{P}-\mathrm{V}$ alue } \\
\hline & & \multicolumn{2}{|c|}{ Pretest } & \multicolumn{2}{|c|}{ Post-test } & & \multicolumn{2}{|c|}{ Pretest } & \multicolumn{2}{|c|}{ Post-test } & \\
\hline & & $\mathrm{R}$ & $\mathrm{L}$ & $\mathrm{R}$ & $\mathrm{L}$ & & $\mathrm{R}$ & $\mathrm{L}$ & $\mathrm{R}$ & $\mathrm{L}$ & \\
\hline \multirow{3}{*}{ Ankle } & Dorsiflexion & 5 & 5 & 5 & 5 & n.s. & 4 & 5 & 4 & 5 & n.s. \\
\hline & Valgus & 5 & 5 & 5 & 5 & n.s. & 4 & 5 & 4 & 5 & n.s. \\
\hline & Varus & 5 & 5 & 5 & 5 & n.s. & 4 & 5 & 4 & 5 & n.s. \\
\hline Knee & Extension & 5 & 5 & 5 & 5 & n.s. & 4 & 5 & 4 & 5 & n.s. \\
\hline \multirow{2}{*}{ Hip } & Flexion & 5 & 5 & 5 & 5 & n.s. & 4 & 5 & 4 & 5 & n.s. \\
\hline & Extension & 5 & 5 & 5 & 5 & n.s. & 4 & 5 & 4 & 5 & n.s. \\
\hline
\end{tabular}

median n.s.: not significant

Normal: 5 Good: 4 Fair: 3 Poor: 2 Trace: 1 Zero: 0

では平均年齢が高く入院中の高齢者を対象としている点 は異なるが，EFを用いることで運動学習が促進的に作 用した点については同様の結果となった. Cross Testで の運動課題においては, EF の教示を行なったことで「床」 に意識が向き, 足底から求心性の情報入力が得られやす く，それに伴い運動方向が明確になった可能性がある。 足底部には感覚情報を集積する機械受容器が多数存在し ており, 床反力として求心性情報を提供するといわれて いる ${ }^{16)}$. 足圧受容器の働きを重心動摇計で検証した研究
では，足底を冷却し足圧情報入力を減少させると静止立 位時の足圧中心動摇面積は増加し, Cross Testに损い ては前後方向への移動可能点が後方に位置したと報告し ている ${ }^{17)}$ 。また, 藤田ら ${ }^{18)}$ は後期高齢者を対象とした 検証で硬度の異なるスポンジマットの弁別を足底で行う ことにより立位姿勢バランスが向上し, 能動的に感覚を 探索することでバランスの向上がみられたと報告してい る。これらから, 運動中に身体外部に注意を向けること は感覚情報を得られやすくなり,この度のCross Testを 
用いた研究においても運動学習が促進的に作用したと考 えられる。

一方で，IFを用いたCross Testに抢いては運動学習 の効果が認められなかった。要因としてIFの教示によ り身体に注意を向けたことで足底の感覚受容器から求心 性の情報が得られにくく運動方向が理解されにくかった 可能性がある. Cross Testでは足関節のストラテジーを 用いた随意的な重心移動の運動課題のため身体の傾斜は 比較的小さいことが考えられる，同程度の加速度に対し て前庭系からの信号に対する筋の応答は, 足部の移動に 生じる体性感覚の応答と比較して10分の 1 であるといわ れている ${ }^{16)}$.これらから身体に注意を向けたことで足部 を除いた体性感覚や前庭系からの求心性の情報は $\mathrm{EF}$ を 用いた場合より比較的少なく運動方向が明確にならずに 学習が進まなかったと考えられる。

また，EF群とIF群に打けるCross Test改善率と BBS, TUG, TMT-Aについてはそれぞれの群において 相関がなかった. BBS, TUGに打いてはどちらの対象者 群も転倒のカットオフポイントである49点 ${ }^{19)}, 13.5$ 秒 ${ }^{20)}$ よりも数值が低かった. しかし, TUGに際し, 対象者は 杖または補装具なしで歩行可能であり, 身体機能の低下 は軽度であったことが相関を認めなかった理由と考えら れる. TMT-Aについては，60歳～85歳までの健常者の 平均值は52.6 17.4 (25-110) 秒 ${ }^{21)}$ で 300秒以上要するも のは認知機能の低下が疑われ ${ }^{22)}, \mathrm{EF}$ 群は225.6 \pm 102.8 秒, IF 群は235.5 106.3 秒であった。 これらから, 認知機能 の低下までは至っていないが, 健常者の平均值と比較す ると $\mathrm{EF}$ 群, IF 群のいずれも注意機能の軽度低下の傾向 が認められた。

以上から, 本研究の対象者のような疾患を問わず軽 度の身体機能の低下や注意機能が低下しているものは, EFの教示によりCross Testでの運動学習を促進的に作 用させる可能性が示唆された。したがって, 運動学習を 目的に運動課題を遂行するうえで, 課題中のフィード バックを身体内部の変化量によって求めるのではなく, 身体外部からの情報量を増加させることでフィードバッ クが分かりやすくなり運動学習が促される可能性があ る. 注意方向についての研究ではQuadriceps Settingの 課題において, 膝を伸ばす教示よりも「枕」を使用する $\mathrm{EF}$ を用いた教示の方が筋電図の值が増大したと報告さ れて抢り ${ }^{23)}$ ，注意方向を変えることでパフォーマンスは 向上すると考元られる。本研究に打いて対象者は軽度の 身体機能の低下や注意機能が低下している入院中の高齢 者のため疾患の影響を受けにくい状態であったと推察さ れる。

Cross Testは立位姿勢からの随意的な安定性限界を計 測するもので, 必要な機能として前方移動では下腿三頭 筋や足趾屈筋の筋力, 足関節背屈の可動性, ハムストリン
グスの柔軟性などが, 後方に移動する際には, 前脛骨筋や 足趾伸筋, 大腿四頭筋の筋力, 側方移動では支持側下肢の 足関節外反位支持機構が関与するといわれている24). 本 研究ではCross Testに必要とされる足関節底屈筋の筋力 が計測できず，他の筋力の計測においても MMTでは詳 細な運動機能の変化を捉えることが十分ではなかったと 思われる。また，EF群とIF群のCross Testでの矩形面 積の経過に执いて最も学習の効果が期待できる14日目に 有意差が出なかった要因として, Cross Testの練習と運 動療法を平行して行なっていたことや，身体機能が低下 しているものを対象としたため, 学習が完全に成立し一 定のパフォーマンスを出すまでに時間がかかったことが 推察される.

また，他の身体機能が改善していないにも関わらずに $\mathrm{EF}$ 群, IF 群のCross Testの改善度が異なることは, 対 象者の予備能力内の変化であることが推察されるため, 今後は運動課題の難易度の設定や練習回数, 詳細な運動 機能の計測についての検討が必要と思われる.

\section{結 論}

本研究はEF と IFのどちらがCross Testにおいて運動 学習に有効なのか入院中の高齢者を対象に身体機能, 注 意機能から検討し明らかにすることを研究目的とした。 結果, EF 群の方がIF群よりもCross Testでの運動学習 に促進的に作用した。しかし， EF 群と IF 群のそれぞれ の改善率と身体機能, 注意機能との間に相関は認められ なかった，軽度の身体機能，注意機能の低下のある高齢 者であればEFを用いることでCross Testでの運動学習 は促進的に作用することが示唆された。

利益相反自己申告：申告すべきものはなし

\section{引用参考文献}

1) Wulf G (福永哲夫, 水藤 健, 沼尾 拓訳). 注意と運動学 習一動きを変える意識の使い方一, 市村出版, 東京, 81102, 2010.

2) 水藤 健, 渡邊 罢, 寺尾育子, 沼尾 拓: 外的焦点 (external focus）を応用した歩行トレーニング, 理学療法, 29: 759-765, 2012.

3) Wulf G, Höß M, Prinz W. Instructions for motor learning: differential effects of internal versus external focus of attention. J Mot Behav 30: 169-179, 1998.

4) Wulf G, Weigelt M, Poulter D, Mcnevin N. Attentional focus on suprapostural tasks affects balance learning. Q J Exp Psychol A 56: 1191-1211, 2003.

5) Shumway-cook A, Woollacott M（田中 繁, 高橋 明監 訳). モーターコントロールー研究室から臨床実践へ-, 医薬出版, 東京, 23-47, 2013.

6）大橋ゆかり，運動学習の効果は永続的なもの一運動学習 の定義と実験デザインー, セラピストのための運動学習 
ABC, 7-14, 文光堂, 2004.

7）月村泰治, 池田珠江：起立の安定域の検討（1）-脳性 麻痺におけるCross Test-, リ八医学, 19: 25-32, 1982.

8）石川 朗, 武藤美穂子, 佐伯秀一, 森川 亘, 原秀幸, 杉野 由佳, 滝野勝昭, 田中繁, 羽田康司, 三上真弘: 平衡機能 検査を目的としたCross Testの有効性, 理学療法学, 21: 186-194, 1994.

9) 内山 靖, 小林 武, 潮見泰藏. Functional Balance Scale (FBS), 臨床評洒指標入門一適用と解釈のポイントー, pp103-108, 協同医書出版社, 2003.

10) Berg K, Wood-Dauphinee S, Williams JI, Gayton D. Measuring balance in the elderly: preliminary development of an instrument. Physiotherpy Canada 41: 304311, 1989 .

11) Podsiadlo D, Richardson S. The timed "Up and Go: a test of basic functional mobility for frail elderly persons. J Am Geriatr Soc 39: 142-148, 1991.

12）高岡 徹, 尾崎浩子：Trail Making Test, 臨床リハ, 18: 246-250, 2009.

13）藤澤宏幸, 武田涼子, 村上賢一, 鈴木 誠, 吉田忠義, 梁川 和也：ファンクショナル・リーチを用いた姿勢最適化 トレーニングにおける internal focus of attention と external focus of attentionの教示効果の差異について, 理 学療法の歩み, 21: 23-31, 2010.

14) Chiviacowsky S, Wulf G, Wally R. An external focus of attention enhances balance learning in older adults. Gait Posture 32: 572-575, 2010.

15) Wulf G, Mcnevin NH. Simply distracting learners is not enough: more evidence for the learning benefits of an external focus of attention. Eur J Sport Sci 3: 1-13, 2003.
16）大杉紘徳：足底感覚, PT ジャーナル, 49: 1023, 2015.

17）浅井仁, 奈良 勲, 立野勝彦, 藤原勝夫, 山下美津子：極低 温空気による足底冷却が安静時立位姿勢調節及び有効 支持基底面の広さに及ぼす影響, 理学療法学, 18: 19-25, 1991.

18）藤田浩之, 中野英樹, 粕渕賢志, 森岡 周 : 後期高齢者の 立位姿勢バランスに対する足底知覚トレーニングの介 入効果-施設入所後期高齢者における無作為化比較試 験による検討-, 理学療法科学, 27: 199-204, 2012.

19) Shumway-cook A, Baldwin M, Polissar NL, Gruber W. Predicting the probability for falls in communitydwelling older adults. Phys Ther 77: 812-819, 1997.

20) Shumway-cook A, Brauer S, Woollacott M. Predicting the probability for falls in community-dwelling older adults using the Timed Up\&Go test. Phys Ther 80: 896-903, 2000.

21）原田浩美, 能登谷晶子, 中西雅夫, 藤原奈佳子, 井上克 己：健常高齢者における神経心理学検査の測定值一年 齢・教育年数の影響-, 高次脳機能研究, 26: 16-24, 2006.

22）岩瀬弘明, 村田伸, 日沖義治, 北尾沙友里, 中村純子, 中 井良哉, 村上貴士, 空場勝之: Trail Making Testと Mini-Mental State Examination との関連-簡便な認 知機能低下の識別方法の検討 -, Japanese Journal of Health Promotion and Physical Therapy 3: 1-4, 2013.

23）光田尚代, 高木綾一, 鈴木俊明：Quadriceps Setting にお ける理学療法士の介入方法が大腿四頭筋の筋活動に及 ぼす影響-Internal focus と External focusによる検討一, 関西理学, 12: 35-39, 2012.

24）福山勝彦, 丸山仁司：Cross testと他のバランス検査と の関係, 理学療法科学, 25: 79-83, 2010. 